\title{
Randomized Comparative Study of Chloroquine and Halofantrine in Vivax Malaria Patients*
}

\author{
Emiliana Tjitra, ${ }^{1}$ Sri Oemijati, ${ }^{2}$ Wita Pribadi, ${ }^{2}$ P.R. Arbani, ${ }^{3}$ P.N. Harianto, ${ }^{4}$ Popy Kawulur ${ }^{4}$ and Marvel Renny ${ }^{1}$
}

\begin{abstract}
Abstrak
Kasus malaria vivaks resisten terhadap klorokuin dan malaria vivaks pasca transfusi yang resisten terhadap klorokuin dan kina telah dilaporkan di Indonesia. Oleh sebab itu dilakukan penelitian acak klorokuin dan halofantrin pada penderita malaria vivaks untuk membandingkan efikasi dan keamanan obat tersebut. Penelitian dilakukan di RS Bethesda, Tomohon, Sulawesi Utara, Indonesia. Penderita dirawat selama 5 hari dan diobati dengan klorokuin $25 \mathrm{mg} / \mathrm{kg}$ BB dalam 3 dosis untuk 3 hari atau halofantrin $1500 \mathrm{mg}$ dalam 3 dosis setiap 6 jam, disertai primakuin $15 \mathrm{mg}$ basa/hari selama 14 hari. Selama penelitian, penderita tidur di dalam kelambu yang dicelup insektisida dan diikuti perkembangannya selama 28 hari. Pada saat masuk rumah sakit, tidak ditemukan perbedaan bermakna antara kelompok klorokuin dan halofantrin dalam karakteristik, gejala klinis dan hasil pemeriksaan laboratorium, kecuali jumlah parasit lebih tinggi pada kelompok klorokuin dan fosfatase alkali lebih tinggi pada kelompok halofantrin. Angka bebas parasit ( angka kesembuhan ) dan rata-rata waktu bebas parasit dari klorokuin ( $100 \%$ dan 48,0 $\pm 18,9$ jain ) vs halofantrin (95,5\% dan 61,5 $\pm 21,6$ jam ) tidak berbeda bermakna. Walaupun demikian rata-rata waktu bebas panas pada klorokuin ( 18,9 $\pm 16,1$ jam ) lebih pendek dibandingkan halofantrin (21,9 $\pm 24,8$ jam ). Parameter biokimia kedua kelompok tersebut setelah pengobatan adalah dalam batas nilai-nilai normal. Efek samping klorokuin dan halofantrin tidak berbeda bermakna, bersifat ringan dan sembuh tanpa pengobatan. Ternyata klorokuin masih sangat efektif, halofantrin juga menunjukkan hasil yang baik dan aman untuk pengobatan malaria vivaks di daerah ini.
\end{abstract}

\begin{abstract}
Cases of vivax malaria resistant to chloroquine and post transfusion vivax malaria resistant to chloroquine and quinine have been reported in Indonesia. In order to compare the efficacy, tolerance and side effects of chloroquine and halofantrine in the treatment of vivax malaria patients, a randomized study was carried out in Bethesda Hospital, North Sulawesi, Indonesia. All patients were hospitalized for 5 days and treated with chloroquine $25 \mathrm{mg}$ base/ $\mathrm{kg} B W$ in 3 doses over 48 hours or halofantrine $1500 \mathrm{mg}$ in 3 doses at 6 hour intervals, both with primaquine $15 \mathrm{mg}$ base/day for 14 days. During the study, the subjects slept under impregnated bed nets and were followed up for 28 days. On admission, the chloroquine and halofantrine groups were not significantly different in presenting characteristics or physical and laboratory examinations, except the parasite count was higher in the chloroquine group and alkaline phosphatase was higher in the halofantrine group. The rate of parasite clearance and the mean parasite clearance time of chloroquine $(100 \%$ and $48.0 \pm 18.9$ hours) vs halofantrine $(95.5 \%$ and $61.5 \pm 21.6$ hours) were not significantly different; however the mean fever clearance time of chloroquine (18.9 \pm 16.1 hours) was shorter than halofantrine $(21.9 \pm 24.8$ hours $)$. No abnormal biochemical parameter was found in either group. The side effects of chloroquine and halofantrine were not significantly different; they were mild and self-limiting. While chloroquine was still very effective, halofantrine also showed a good response and was safe for treatment of vivax malaria in the study area.
\end{abstract}

Keywords: Vivax malaria, treatment, chloroquine, halofantrine

* This paper had been presented at VIII International Congress of Parasitology. 10-14 October 1994. Izmir, Turkey.

1. Communicable Diseases Research Center, National Institute of Health Research and Developmment, Ministry of Health, Jakarta, Indonesia.

2. Department of Parasitology, Faculty of Medicine, University of Indonesia, Jakarta, Indonesia.

3. Directorate General of Communicable Disease Control and Environmental Health, Ministry of Health, Jakarta, Indonesia.

4. Bethesda Hospital, Tomohon, North Sulawesi, Indonesia. 


\section{INTRODUCTION}

Plasmodium vivax and $P$. falciparum are the most common species of malaria parasites in Indonesia. Even though most of the studies were focussed mainly on $P$. falciparum because of the relevance of that species to human life, on the contrary, $P$. vivax infection which is generally considered to be benign, could also decrease daily working activities and productivity.

At present, chloroquine is still the drug of choice for malaria treatment and prophylaxis. Resistance of malaria parasites to chloroquine has until recently been restricted to $P$. falciparum. Cases of falciparum malaria resistant to chloroquine have been reported from all provinces of Indonesia. ${ }^{1}$ Recurrent parasitemia in vivax malaria following therapy has often been interpreted as relapse, which is characteristic of this species. However, $P$. vivax resistant to chloroquine due to natural infection and post transfusion vivax malaria resistant to chloroquine and quinine have been reported in Indonesia. ${ }^{2-5}$ Cases of vivax malaria resistant to chloroquine have also been reported from Papua New Guinea and Myanmar. ${ }^{6-7}$ The spread of parasites resistant to antimalarial drugs threatens the community in malarious areas.

Halofantrine is a new antimalarial from phenanthrenemethanol group. It is effective against the asexual erythrocyte stage of malaria parasites. Halofantrine is indicated for the treatment of acute malaria caused by single or mixed infections of $P$. falciparum and $P$. vivax. Clinical trials of halofantrine in patients with acute malaria showed high efficacy and few side effects in areas of prevalent chloroquine resistance ${ }^{8-10}$. This drug is not yet registered in Indonesia. There is a need to evaluate new drug as alternative for the treatment of vivax malaria in Indonesia.

In order to compare the efficacy, tolerance and side effects of chloroquine and halofantrine in the treatment of vivax malaria patients, a randomized study of chloroquine and halofantrine was performed.

\section{MATERIALS AND METHODS}

This is a collaborative study between the Ministry of Health, Jakarta; the University of Indonesia, Jakarta; and the Bethesda Hospital, North Sulawesi, Indonesia.

\section{Study site and duration of study}

The study was carried out at Bethesda Hospital, North Sulawesi, Indonesia during January-September 1993.

\section{Study design}

The study was a randomized, comparative study of chloroquine plus primaquine versus halofantrine plus primaquine in patients infected with $P$. vivax.

\section{Patients}

A total of 94 vivax malaria patients had been selected according to WHO criteria for in vivo antimalarial sensitivity testing ${ }^{11}$ :

1. More than 12 years of age.

2. Blood smear positive for asexual forms of $P$. vivax with minimal count $1,000 / \mathrm{Ul}$.

3. Without complications or other diseases.

4. Non-pregnant or non-lactating females.

5. No administration of antimalarial during the last 14 days, urine test negative on Dill-Glazko and Lignin test.

6. Could swallow the drug.

7. No history of hypersensitivity to antimalarials.

8. Willingness to participate and sign the informed consent form.

\section{Setting}

All patients were hospitalized and slept under insecticide- impregnated bed nets to prevent exposure to mosquito biting. They were kept in the hospital for 3-5 days or until clinically and parasitologically cured.

\section{Investigations}

A thorough history was taken and physical examinations performed on study subjects from time of admission onwards. Daily axillary temperatures were taken at $6^{\circ 0}, 10^{\circ 0}, 14^{\circ 0}, 18^{\circ 0}$ and $22^{\circ 0}$ hours until the temperature maintained at $<37,5^{\circ} \mathrm{C}$ for a whole day. Then temperature was recorded daily.

Parasite counts were done every 12 hours until the smears remained negative for 36 hours. Patients were then followed daily until discharged from the hospital.

Routine haematology (haematocrit, haemoglobin, red cell count, white cell count and platelet count) and biochemistry (SGOT, SGPT, alkaline phosphatase, bilirubin, protein BUN, creatinine and glucose) exams were conducted on admission (pretreatment) and on discharge (post-treatment).

\section{Treatment}

Forty-nine of 94 vivax malaria patients were treated with chloroquine orally $10 \mathrm{mg}$ base $/ \mathrm{kg} \mathrm{BW} /$ day in single dose on Day 1 and D2 then followed by $5 \mathrm{mg}$ 
base/kg BW/day in single dose on D3. The other 45 vivax malaria patients were treated with halofantrine orally $500 \mathrm{mg} 6$ hourly for 3 doses. Both groups also received primaquine $15 \mathrm{mg}$ base/day orally for 14 days begining on the same day of antimalarial therapy.

\section{Follow-up}

The patients were followed up to D28. On discharge, they were given multivitamins and insecticide-impregnated bed nets. Subjects were instructed not to take other antimalarials during the study and to immediately report to the hospital if they became sick. They were also instructed to sleep under mosquito net.

The blood smears were rechecked for malaria parasites on D7, D14, D21 and D28.

\section{Treatment of recurrent parasitemia cases}

Vivax malaria patients who had been treated with chloroquine or halofantrine and developed recurrent parasitemia were treated with another course of chloroquine or halofantrine. After treatment was completed, they were put under observation for 14 days. If they developed recurrent parasitemia again, they were treated with quinine $3 \times 400 \mathrm{mg} /$ day for 7 days.

\section{Statistical analysis}

Chi-square $\left(x^{2}\right)$ and Fisher's exact tests were used to compare the nonparametric characteristics, clinical events and cure rates of chloroquine and halofantrine groups. Unpaired Student's t-test was used to compare the parametric characteristics, haematology and biochemistry values, fever and parasite clearance times of those groups.

\section{RESULTS}

During the study, a total of 2.291 cases with positive malaria had been detected, among them 1.093 (47.8\%) were $P$. vivax infections, $1.162(50.7 \%)$ were $P$. falciparum and $36(1.5 \%)$ were mixed infection of $P$. falciparum and $P$. vivax.

Among $1.093 P$. vivax cases, 94 patients were selected according to the protocol criteria. Of the 94 vivax patients, only 41 cases in the chloroquine group and 44 cases in the halofantrine group had completed the study and were able to be followed up until D28. They were all from Minahasa; 60 males and 25 females; ranging in age, weight and height between 13 and 73 years, 40 and $72 \mathrm{~kg}$, and 145 and $180 \mathrm{~cm}$, respectively. Less than $50 \%$ had previously ex- perienced a malaria attack. Axillary temperatures and parasite counts ranged between 36 and $40.4^{\circ} \mathrm{C}$, and 1,000 and $132,600 / u l$, respectively.

\section{Comparative characteristics between treatment groups}

Comparison of the parameters ( age, sex, weight, height, race, previous history of malaria and temperature ) revealed no significant differences between the two groups except the parasite counts were slightly higher in the chloroquine group (Table 1).

Table 1. Comparison of characteristics of vivax malaria patients between the treatment groups on admission at Bethesda Hospital, Tomohon, North Sulawesi, Indonesia, 1993.

\begin{tabular}{|c|c|c|c|c|c|}
\hline \multirow{2}{*}{$\begin{array}{c}\text { Characteristic } \\
\mathrm{Age}=(\mathrm{X} \pm \mathrm{SD}) \text { year }\end{array}$} & \multicolumn{2}{|c|}{ Chloroquine } & \multicolumn{2}{|c|}{ Halofantrine } & \multirow{2}{*}{$\begin{array}{c}\begin{array}{c}\text { Statistical } \\
\text { analysis }\end{array} \\
\text { NS }\end{array}$} \\
\hline & 30.8 & \pm 11.6 & 31.3 & \pm 15.5 & \\
\hline Sex = male $:$ female & 28 & $: 13$ & 32 & $: 12$ & NS \\
\hline Weight $=(X \pm S D) \mathrm{kg}$ & 56.3 & \pm 7.0 & 56.5 & \pm 6.8 & NS \\
\hline Height $=(X \pm S D) \mathrm{cm}$ & 159.9 & \pm 7.2 & 160.4 & \pm 8.5 & NS \\
\hline Race = Minahasa : & & & & & \\
\hline others & 41 & $: 0$ & 42 & $: 0$ & NS \\
\hline $\begin{array}{l}\text { Malaria previously } \\
\quad=\text { Yes }: \text { No }\end{array}$ & 17 & $: 24$ & 18 & $: 26$ & NS \\
\hline $\begin{array}{l}\text { Axillary lemperalure } \\
\qquad=(X \pm S D)^{\circ} \mathrm{C}\end{array}$ & 37.7 & \pm 1.2 & 37.6 & \pm 1.3 & NS \\
\hline $\begin{array}{l}\text { Parasite count } \\
\qquad=(X \pm S D) / \mu l\end{array}$ & 9,67 & $6 \pm 20,620$ & 9,25 & $\pm 10,521$ & $\mathrm{p}<0.05$ \\
\hline
\end{tabular}

NS $=$ Not Significant

Comparative clinical events between treatment groups

The most frequent ( $>50 \%$ ) clinical symptoms and signs in both groups were fever, headache, nausea and chills. However, there were no significant difference between the two groups (Table 2).

\section{Comparative laboratory test results between treat- ment groups.}

Results of routine haematology and biochemistry examinations showed within normal values on admission (pre-treatment). However, the platelet counts were low $(<150 / \mathrm{nl})$ and total bilirubin were slightly high $(>1.1$ $\mathrm{mg} \%$ ) in both groups. Further analysis showed a significant difference for the alkaline phosphatase (Table $3)$. 
Table 2. Comparison of clinical events of vivax malaria patients between the treatment groups on admission at Bethesda Hospilal, Tomohon, North Sulawesi, Indonesia, 1993.

\begin{tabular}{lccc}
\hline Clinical event & $\begin{array}{c}\text { Chloroquine } \\
\#(\%)\end{array}$ & $\begin{array}{c}\text { Halofantrine } \\
\#(\%)\end{array}$ & Chi-square lest \\
\hline Fever & $40(97.6)$ & $40(90.9)$ & NS \\
Headache & $39(95.1)$ & $42(95.5)$ & NS \\
Nausea & $30(73.2)$ & $37(84.1)$ & NS \\
Chill & $29(70.7)$ & $28(63.6)$ & NS \\
Splenomegaly & $17(41.5)$ & $13(29.5)$ & NS \\
Dizziness & $16(39.0)$ & $19(43.2)$ & NS \\
Hepatomegaly & $14(34.1)$ & $10(22.7)$ & NS \\
Abdominal pain & $12(29.3)$ & $12(27.3)$ & NS \\
Voniting & $9(22.0)$ & $12(27.3)$ & NS \\
Cough & $5(12.2)$ & $1(2.3)$ & NS \\
Palpitation & $3(7.3)$ & $6(13.6)$ & NS \\
Diarthoea & $2(4.9)$ & $2(4.5)$ & NS \\
Itching & 0 & $1(2.3)$ & NS \\
Others & $2(4.9)$ & 0 & NS \\
& & &
\end{tabular}

NS = Not Significant

Table 3. Comparison of laboratory lests of vivax malaria patients between the treatment groups on admission (pre-treatment) at Bethesda Hospital, Tomohon, North Sulawesi, Indonesia, 1993.

\begin{tabular}{lrrl}
\hline Laboratory lest & $\begin{array}{r}\text { Chloroquine } \\
(\mathrm{X} \pm \mathrm{SD})\end{array}$ & $\begin{array}{c}\text { Halofantrine } \\
(\mathrm{X} \pm \mathrm{SD})\end{array}$ & $\begin{array}{l}\text { Student's } \\
\text { l-lest }\end{array}$ \\
\hline Haematocrit (\%) & $39.6 \pm 5.2$ & $41.7 \pm 4.7$ & NS \\
Haemoglobin (g\%) & $12.6 \pm 1.8$ & $12.9 \pm 1.4$ & NS \\
Red cell count (/pl) & $4.4 \pm 0.6$ & $4.7 \pm 0.7$ & NS \\
White cell count (/nl) & $8.2 \pm 2.2$ & $8.7 \pm 2.4$ & NS \\
Platelet (/nl) & $134.3 \pm 51.4$ & $123.5 \pm 67.5$ & NS \\
SGOT/ASAT (IU) & $14.4 \pm 7.5$ & $17.0 \pm 8.5$ & NS \\
SGPT/ALAT (IU) & $15.6 \pm 10.9$ & $15.7 \pm 13.4$ & NS \\
Alkaline phosphatase (IU) & $124.1 \pm 43$ & $158.8 \pm 85.8$ & p<0.05 \\
Total bilirubin (mg \%) & $1.3 \pm 0.7$ & $1.4 \pm 0.7$ & NS \\
Protein (mg \%) & $6.9 \pm 0.6$ & $6.9 \pm 0.7$ & NS \\
BUN (mg \%) & $27.1 \pm 8.6$ & $29.1 \pm 8.8$ & NS \\
Crcatinine (mg \%) & $0.9 \pm 0.3$ & $1.1 \pm 0.2$ & NS \\
Glucose (mg \%) & $121.6 \pm 33.6$ & $118.7 \pm 31.2$ & NS \\
\end{tabular}

NS $=$ Not Significant

The results of all laboratory tests from both groups were within normal values on discharge from the hospital (post-treatment). However, the two groups showed significant differences in the white cell counts, SGOT/ASAT, SGPT/ALAT, alkaline phosphatase and BUN (Table 4).
Table 4. Comparison of laboratory tests of vivax malaria patients between the treatment groups on discharge (post-treatment) at Bethesda Hospital, Tomohon, North Sulawesi, Indonesia, 1993.

\begin{tabular}{|c|c|c|c|}
\hline Laboratory test & $\begin{array}{c}\text { Chloroquine } \\
(X \pm S D)\end{array}$ & $\begin{array}{c}\text { Halofantrine } \\
(X \pm S D)\end{array}$ & $\begin{array}{l}\text { Student's } \\
\text { t-test }\end{array}$ \\
\hline Haemalocrit $(\%)$ & $38.8 \pm 4.7$ & $38.6 \pm 4.3$ & NS \\
\hline Haemoglobin ( $\mathrm{g} \%$ ) & $12.1 \pm 1.6$ & $12.0 \pm 1.5$ & NS \\
\hline Red cell count $(\mid \mathrm{pl})$ & $4.4 \pm 0.6$ & $4.4 \pm 0.8$ & NS \\
\hline White cell count $(|\mathrm{n}|)$ & $8.6 \pm 2.0$ & $8.9 \pm 2.7$ & $\mathrm{p}<0.05$ \\
\hline Platelel (/nl) & $217.0 \pm 70.9$ & $218.7 \pm 70.3$ & NS \\
\hline SGOT/ASAT (IU) & $12.8 \pm 4.9$ & $14.8 \pm 8.4$ & $p<0.05$ \\
\hline SGPT/ALAT (IU) & $14.1 \pm 7.7$ & $14.5 \pm 12.3$ & $\mathrm{p}<0.05$ \\
\hline \multicolumn{4}{|l|}{ Alkaline phosphatase } \\
\hline (IU) & $117.8 \pm 41.7$ & $141.5 \pm 84.4$ & $p<0.05$ \\
\hline Total bilirubin (mg \%) & $0.7 \pm 0.3$ & $0.7 \pm 0.3$ & NS • \\
\hline Prolein (mg \%) & $7.4 \pm 0.7$ & $7.4 \pm 0.6$ & NS \\
\hline BUN (mg \%) & $23.9 \pm 7.0$ & $23.1 \pm 10.4$ & $p<0.05$ \\
\hline Crcalinine (mg \%) & $0.9 \pm 0.2$ & $0.8 \pm 0.2$ & NS \\
\hline Glucose (mg \%) & $97.5 \pm 20.8$ & $100.2 \pm 27.4$ & NS \\
\hline
\end{tabular}

NS $=$ Not Significant

\section{Comparative efficacy between treatment groups}

The cure rate in the chloroquine group was $100 \%$ (41/41). The cure rate in the halofantrine group was $95.5 \%(42 / 44)$ because of the presence of early resistance stage I (R I) and late R I cases. The fever clearance time ranged from $0-64$ hours in the chloroquine group and from 0-74 hours in the halofantrine group. The mean fever clearance times $(18.9 \pm 16.1$ hours vs $21.9 \pm 24.8$ hours) were significantly different between the two treatment groups. The parasite clearance time ranged from 18-100 hours in the chloroquine group and from 22-100 hours in the halofantrine group. The mean parasite clearance times between these groups ( $48.0 \pm 18.9$ hours vs $61.5 \pm 21.6$ hours) were not significantly different (Table 5 ).

Tuble 5. Comparison of antimalarial efricacy in vivax malaria patients between the trealment groups at Bethesda Hospital, Tomohon, North Sulawesi, Indonesia, 1993.

\begin{tabular}{lccl}
\hline \multicolumn{1}{c}{ Eflicacy } & Chloroquine & Halofantrine & $\begin{array}{l}\text { Chi-square/ } \\
\text { Student's } \\
\text { t-test }\end{array}$ \\
\hline $\begin{array}{l}\text { Parasile clearance rate(\%) } \\
100(41 / 41)\end{array}$ & $95.5(42 / 44)$ & NS \\
$\begin{array}{l}\text { Fever clearance time } \\
(X \pm \text { SD ) hour }\end{array}$ & $18.9 \pm 16.1$ & $21.9 \pm 24.8$ & $\mathrm{p}<0.05$ \\
$\begin{array}{l}\text { Parasile clearance time } \\
(\mathrm{X} \pm \text { SD }) \text { hour }\end{array}$ & $48.0 \pm 18.9$ & $61.5 \pm 21.6$ & NS \\
\hline
\end{tabular}

NS $=$ Not Significant 


\section{Comparative side effects between treatment groups}

A side effect was defined as a symptom appearing only after drug administration. During the treatment, several symptoms which were mild and self-limited were noted : abdominal pain, vomiting, itching, nausea, palpitation, diarrhoea, epigastric pain, dizziness and epistaxis (Table 6).

Table 6. Comparison of side effects of antimalarial in vivax malaria patients between the treatment groups at Bethesda Hospital, Tomohon, North Sulawesi, 1993.

\begin{tabular}{lccc}
\hline Side effects & $\begin{array}{c}\text { Chloroquine } \\
\#(\%)\end{array}$ & $\begin{array}{c}\text { Halofantrine } \\
\#(\%)\end{array}$ \\
\hline Abdominal pain & $4(9.8)$ & $2(4.5)$ \\
Vomiting & $3(7.3)$ & 2 & $(4.5)$ \\
Itching & $3(7.3)$ & 0 & \\
Nausea & $2(4.9)$ & 2 & $(4.5)$ \\
Palpitation & $2(4.9)$ & 0 & 1 \\
Diarthoea & $1(2.4)$ & 0 \\
Epigastric pain & $1(2.4)$ & 0 \\
Dizziness & 0 & 3 & $(6.8)$ \\
Epistaxis & 0 & 1 & $(2.3)$ \\
\hline
\end{tabular}

\section{DISCUSSION}

This study was conducted in acute uncomplicated vivax malaria patients with general symptoms and signs. ${ }^{12-13}$ Slight thrombocytopenia and hyperbilirubinemia were found in these patients, and these signs often appeared in falciparum malaria patients. 9 $10,14-15$

The Ministry of Health has recommended treatment of vivax malaria with chloroquine $25 \mathrm{mg}$ base/ $\mathrm{kg} \mathrm{BW/} 3$ days and primaquine $15 \mathrm{mg}$ base/day for 5 days. This regimen showed a good response with relapse rate about $10-12 \% .{ }^{16}$ In this study a similar regimen of chloroquine was used except that primaquine (15 $\mathrm{mg}$ base/day) was given for 14 days as recommended by WHO. ${ }^{17}$ Under this regimen, the parasite clearance was $100 \%(41 / 41)$, the fever and parasite clearance time were $18.9 \pm 16.1$ hours and 48.0 \pm 18.9 hours, respectively.

The first clinical trial of halofantrine in Indonesia was conducted on uncomplicated falciparum malaria; the cure rate was $98.4 \%$, the mean fever and parasite clearance time were rapid ( $22.4 \pm 2.7$ hours and 58.3 \pm 5.2 hours). ${ }^{9}$ The present clinical trial also showed halofantrine with primaquine was effective for the treatment of vivax malaria; the parasite clearance was $95.5 \%$ (42/44), the fever and parasite clearance time were $21.9 \pm 24.8$ hours and $61.5 \pm 21.6$ hours, respectively.
In Thailand, halofantrine treatment for vivax malaria using the same regimen but without primaquine was also highly effective; the parasite clearance was $100 \%$ (21/21), the fever clearance time ( $42.3 \pm$ 19.9 hours ) was longer than in our study, and the parasite clearance time was similar. ${ }^{18}$ The parasite clearance in a study in Solomon Islands was also $100 \%$ ( $8 / 8$ ) but the clearance time (46.5 hours) was shorter than in this study. ${ }^{19}$ A study in Pakistan, showed the parasite clearance $95.4 \%(21 / 22)$, the fever clearance time (57.5 hours) was also longer and the parasite clearance time was slightly shorter than this study. ${ }^{20}$

None of these studies included evaluation of the effect of halofantrine on the relapse of $P$. vivax, as it was assumed not to be effective against liver stages. We also did not measure the post-therapeutic relapse rates, but the regimen of primaquine administration presumably could eliminate the liver stage of the parasites. However in Thailand, the standard radical curative of primaquine dosage had cleared the erythrocytic stages of $P$. vivax. ${ }^{21}$ Halofantrine with or without primaquine, appears to be effective for acute uncomplicated vivax malaria treatment.

Preliminary results of therapeutic trial between halofantrine-primaquine and chloroquine-primaquine for treatment of $P$. vivax infection in Arso, Irian Jaya, Indonesia, gave a cure rate of $100 \%$ and $80 \%$, respectively (Table 7). While in another study, also in Arso, chloroquine-primaquine was shown to be more effective than chloroquine alone in the treatment of vivax malaria (Cumulative Incidence on D28 were $15 \%$ vs $80 \%){ }^{22}$ The blood schizonticidal activity of primaquine might mask chloroquine resistance in combined regimens. $^{21}$

Table 7. Efficacy of Halofantrine-Primaquine (HF-PQ) and Chloroquine-Primaquine (CQ-PQ) for treatment of Plasmodium vivax infections: A comparison of 7- and 28-Day In vivo lest results*.

\begin{tabular}{|c|c|c|c|c|}
\hline \multirow[t]{2}{*}{ Result } & \multicolumn{2}{|c|}{ 7-Day test } & \multicolumn{2}{|c|}{ 28-Day test } \\
\hline & HF-PQ & CQ-PQ & HF-PQ & CQ-PQ \\
\hline $\begin{array}{l}\text { Successful Ireatments } \\
\text { (no recrudescence) }\end{array}$ & 21 & 16 & 21 & 8 \\
\hline Total trealed & 21 & $17 * \star$ & 21 & 10 \\
\hline \multicolumn{5}{|l|}{ Slatistics: } \\
\hline$P$ value & \multicolumn{2}{|c|}{0.99} & \multicolumn{2}{|c|}{0.78} \\
\hline Odds Ratio & \multicolumn{2}{|c|}{1.06} & \multicolumn{2}{|c|}{1.25} \\
\hline
\end{tabular}

* Source : Baird K and Fryaulf D (NAMRU-2). ${ }^{22}$

** 7 cases could not be followed until D28. 
This study showed that chloroquine-primaquine and halofantrine-primaquine were effective for vivax malaria. This comparative study showed a significantly different shorter fever clearance time in the chloroquine group. However, halofantrine fever clearance time was shorter than the other studies ( 21.0 hours vs 42.3 - 57.5 hours $)^{18,20}$ which may be due to increasing blood schizonticidal effect by primaquine. ${ }^{21}$

There was evidence of only mild intolerance of chloroquine and halofantrine which proved self-limiting and resolved rapidly without intervention. However, there was no significant difference between both groups. Laboratory findings showed no evidence of toxicity by chloroquine-primaquine and halofantrineprimaquine either haematologically or biochemically. Our previous study of halofantrine alone in uncomplicated falciparum malaria had similar clinical side effects as compared to the other studies ${ }^{8-9}$

\section{CONCLUSION}

Chloroquine-primaquine was very effective against $P$. vivax in Tomohon, North Sulawesi. Halofantrineprimaquine also gave a good therapeutic response and was safe. On the basis of preliminary evidence reported elsewhere, ${ }^{21,22}$ the efficacy of chloroquine in this study may be dependent upon the administration of primaquine.

\section{Acknowledgements}

The authors would like to thank the followings for their invaluable assistance :

1. Dr. Suriadi Gunawan DPH, Head Communicable Disease Research Center, National Institute of Health Research and Development, Ministry of Health, Republic of Indonesia.

2. The Director and staff, Bethesda Hospital, Tomohon, North Sulawesi, Indonesia.

3. Smith Kline \& French, Jakarta and Singapore.

4. PT ICI Pestisida Indonesia, Jakarta.

5. Kevin Baird PhD, NAMRU-2, Jakarta, Indonesia.

\section{REFERENCES}

1. Arbani PR. Malaria situation in Indonesia. Symposium of $\mathrm{OBC}$. Faculty of Medicine, University of Indonesia, Jakarta, 28 November 1991.

2. Schwarz IK, Lacteritz EM, Patchen LC. Letter: Chloroquine resistant Plasmodium vivax from Indonesia. New Engl I Med 1991; 324: 927.

3. Baird JK, Basri H, Purnomo et al. Resistance to chloroquine by Plasmodium vivax in Irian Jaya, Indonesia. Am J Trop Med Hyg 1991; 44(5): 547-52.
4. Murphy GS, Basri H, Purnomo et al. Vivax malaria resistant to treatment and prophylaxis with chloroquine. Lancet 1993; 341: $96-100$.

5. Tjitra E, Lukito B, Suriadi G. A case report: Multidrug resistant transfusion vivax malaria. Paediatr Indon (inpublish).

6. Schuurkamp GJ, Spicer PE, Keren RK, Bulungol PK. A mixed infection of vivax malaria and falciparum malaria apparently resistant to 4-aminoquinoline : a case report. Trans Roy Soc Trop Med Hyg 1989; 8 : 607-8.

7. Myat-Phone-Kyaw, Myint-Oo, Myint-Lwin et al. Emergence of chloroquine resistant Plasmodium vivax in Myanmar (Burma). Short report. Trans Roy Soc Trop Med Hyg $1993 ; 87: 687$.

8. Horton RJ, Parr SN. Halofantrine: an overview of efficacy and safety. In: Halofantrine in the treatment of multidrug resitant malaria. Parasitology Today, Suppl. Ed Warhurst DC and Schofield CJ. Cambridge, UK : Elsevier Publications, $1989: 65-80$.

9. Tjitra E, Oemijati S, Pribadi W et al. Treatment of uncomplicated falciparum malaria with halofantrine in a chloroquine resistant area. Bull Hlth Studies 1992; 20(1): 1-8.

10. Tjitra E. Oemijati S, Pribadi W et al. Comparative study of halofantrine in uncomplicated falciparum malaria which was in vitro sensitive vs resistant to chloroquine. Bull Hlth Studies 1993; 21(1): 22-31.

11. World Health Organization. Chemotherapy of malaria and resistance to antimalarial. Report of a WHO Scientific group. WHO Tech Rep Ser 1973; 529.

12. Manson-Bahr PEC, Apted FIC. Malaria and Babesiosis. In: 18 th ed Manson's Tropical Disease. London : The English Language Book Society and Bailliere Tindall, 1983 : 38-69.

13. Miller LH. Malaria. In: Tropical and Geographical Medicine. New York : Mc Graw-Hill Book Company, 1984 :223-9.

14. Skudowitz RB, Katz J, Lurie A et al. Mechanism of thrombocytopenia in malignant tertian malaria. $\mathrm{Br}$ Med $\mathrm{J}$ $1973 ; 2: 515-7$.

15. Hall AP, Schneider RJ, Nanakorn A, West HJ. Jaundice in falciparum malaria. Annual Report SEATO Med Research Lab 1975; 234-6.

16. Indonesia Ministry of Health. Treatment (3). In : Malaria. Directorate General of Communicable Disease Control and Environmental Health, Ministry of Health, Republic of Indonesia 1990: 52.

17. World Health Organization. The Clinical Management of Acute Malaria. WHO Regional Publications, South-East Asia Series no 9, 3rd edition. WHO Regional Office for South-East Asia, New Delhi, 1990.

18. Chitchang S, Wongteptien. A clinical trial of halofantrine in acute uncomplicated malaria in Thai soldiers. In : Halofantrine in the treatment of multidrug resistant malaria. Parasitology Today, Suppl. Ed Warhurst DC and Schofield CJ. Cambridge, UK : Elsevier Publications, 1989 : 21-6.

19. Parkinson D, Balmer V, Ajdukiewicz A et al. The effectiveness of halofantrine for the treatment of acute malaria in adults in the Solomon islands. In : Halofantrine in the treatment of multidrug resistant malaria. Parasitology Today, Suppl. Ed Warhurst DC and Schofield CJ. Cambridge, UK : Elsevier Publications, 1989 : 27-35. 
20. Rab SM, Sheikhani MS, Mahmoud SA et al. The efficacy of halofantrine hydrochloride in acute malaria : A study of 74 patients from Karachi, Pakistan. In : Halofantrine in the treatment of multidrug resistant malaria. Parasitology Today, Suppl. Ed Warhurst DC and Schofield CJ. Cambridge, UK : Elsevier Publications, 1989 : 37-44.

21. Pukrittayakamee S, Vanijanonta S, Chantra A et al. Blood stage Antimalarial Efficacy of Primaquine in Plasmodium vivax Malaria. J Infect Dis 1994; 169 (4): 932-5.
22. Frayauff DJ, Baird JK, Basri $\mathrm{H}$ et al. Primaquine adjunct to 28 day evaluation of halofantrine vs chloroquine for therapy of malaria in people remaining exposed to infection in Irian Jaya. Annual meeting of The American Society of Tropical Medicine and Hygiene and The American Society of Parasitologist. Atlanta, Georgia, USA, October 31 - November 4, 1993. 